3 年以下 $5 \sim 10$ 年 $10 \sim 12$ 年

根治照射 17

保存照射 5

根治照射17名の成績は次の如くである.

消失 改善 不変 墨化

的まい発作 $\quad I 7(100 \%) \quad 0 \quad 0 \quad 0$

難 聴 $0 \quad 1(6 \%) \quad 9(53 \%) 7(41 \%)$

耳 鳴 $0 \quad 4(24 \%) 10(59 \%) 3(17 \%)$

めまい発作：全例消失. 術後怪、発作があった例が 5 名あったが，その後の経過で 4 年，6年，6年，9年， 10年と発作が全くないので消失とした，めまい発作の消 失を温度反応との関係でみると, 温度反応高失例では術 後全く発作から解放され，温度反応の残存した例では一 時軽い発作をみた傾向があった，温度反応が少し残った 例です発作が消失したことは半規管の反応性低下と超音 波の治療効果によるものと考えている.

聴力: 術後の聴力の推移については, 術後 $1 \sim 3$ 力月 の聴力はその後ほぼ保たれ増悪する傾向は少ない 術後 $1 \sim 3$ 力の聴力に比べその後の経過で僅かながら改善 を示した例もある。これは超音波がメニエール病の局所 病変に改善を与え, 病的状態の反覆がなくなったことに よるものと考えている。

保存的照射 5 名の成績は次の如くである。

\begin{tabular}{|c|c|c|c|c|}
\hline & 肖失 & 改善 & 不変 & 悪化 \\
\hline めまい発作 & $3(60 \%)$ & $2(40 \%)$ & 0 & 0 \\
\hline 聴 & 0 & $2(40 \%)$ & $1(20 \%)$ & $2(40 \%)$ \\
\hline 鳴 & 0 & $1(20 \%)$ & $2(40 \%)$ & $2(40 \%)$ \\
\hline
\end{tabular}

めまい発作：照射量が少なく温度反忘の残り方が多い と発作反覆に対する効果は落ちる。
聴力：聴力低下が 2 名あるが程度は $15 \mathrm{~dB} ， 23 \mathrm{~dB}$ と軽 度である. 改善例では城值の回復とともに聴力西変動が なくなり，3年の経過において約 $15 \mathrm{~dB}$ の低下を認めた が術前に比べ良い聴力が保たれた。

IV. まとぬ

根治照射, 保存照射成續をあわせ超音波手術の長所, 欠点をあげれば次の如くである。

長所 :

(1) めまい発作に詨する治療効果が確実である（発作 消失91\%)

(2) 治療効果を温度反応で把握できる.

(3) 聴力保存, 改善も可能である（保存 $37 \%$, 改善16 $\%)$

欠点：

(1) 迷路反応が残存するとめまい発作が再現すること がある $(9 \%)$

(2) 聴力低下例がある (40\%)

(3) 顔面神経麻痷をきたすことがある (18\%)

(4) 平衡障害を残す例がある（軽度の平衡障害の自覚 $(50 \%)$

超音波手術はわが国で装置が開発されていないこと， 破喪手術としての印象が強いことよりあまり行かれてい ない.しかし，上述の如く根治照射を行った場合めまい 発作に対する効果は甚だ確実である。難治のメニエール 病には最む優れた治療法だと考えている。

なお，本パネルのため Arslan, Angel James, Stahle に本手術に対する見解を問合わせたが，欧州に掓て超 音波手術が高い評価を得ていることが確認できた。

\title{
内耳病変の選択的部分的摘出術の意義と可能性につい ての検討
}

\author{
鈴 木 淳 一-(帝京大)
}

\section{1）内耳部分破壊術の意義}

メニエール病では，他の内耳疾患にくらべて，内耳の ある部分のみが障害され，他の部分仙健存する，とい。 た状態になることは少ないようである，すなわち，大な り小なり，内耳全体が平均して障害されることが多い．
しかし，程度問題として，比較的に，西る部分に病変 がつよい，他は弱い，といった状態はメニエール病につ いても認められるところであって，内耳全体を破壊せず に, 病宩のみを, また, とくに, 障害をむたらしている 活動的な病巣のみを除去すること：残った部分を健全に 


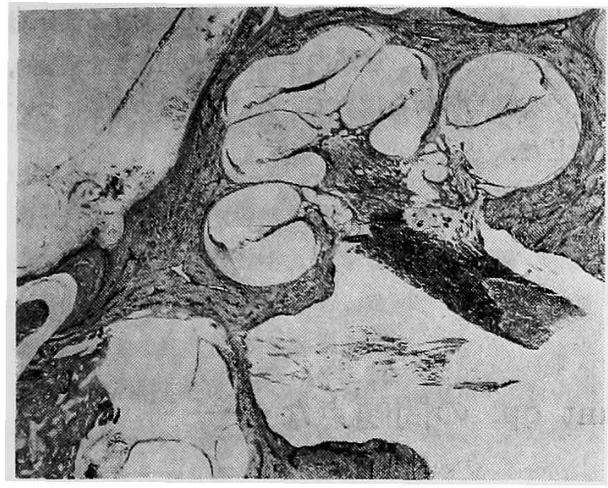

(A)

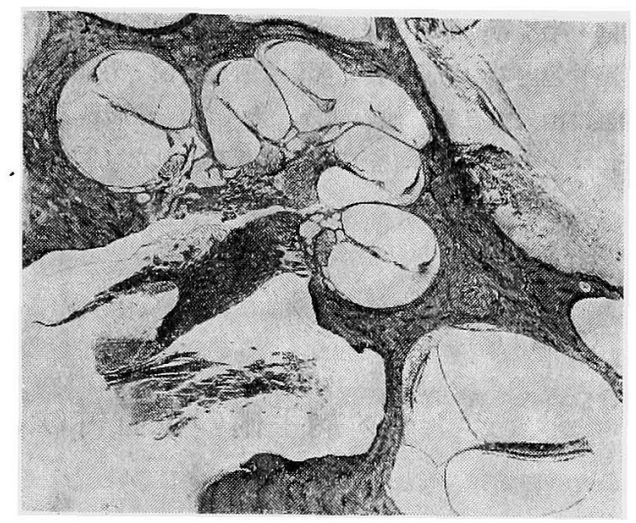

(B)

図 1 赤毛ザルに行った内耳部分破壤

(A) 前庭神経上技切断後, 4 力月. 蝸牛は健在である.

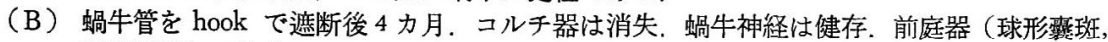
卵形慗斑）は健在。

保存することの意義は，決して小さくはない

\section{2）内耳の部分破壊は何を保存するかについて}

内耳には，一側に，6コの感覚終末装置があって，そ の中の何コかを破壊し，何コかを残す，たとえば，前庭 部分を破壊して，蝸牛を残す，といった部分破壊と，そ れとは異った意味で，たとえば，半規管のクプラを破壊 して,クリスタを保存する,といった部分破壊とがある。

前者を「解剖学的部分破壊」とすれば，後者は，「組織 学的部分破壊」である。

組織学的には, 内耳の 6 コの感覚装置は, す心゙て類似 した構造であって, presensory, sensory, neural の 3 段 階に分けられる，その何れを，部分的に，すなわち選択 的に破壊するかによって，内耳障害のもたらす影響は， 大変に異なる。

内耳の部分破壞は, したがって, 解剖学的, 組織学的 に明確に示すことによって，その障害や残存機能を明ら かにすることができる。

Presensory の部分破壊では，内耳機能のうち，自発 発火が保存される場合が多いので，内耳破壊の障害が小 さい. Sensory では, 神経線維に何らかの病的障害が波 及し, あるいは, 病的信号が中枢に運ばれる可能性がつ よく，耳鳴，あるいは，めまいの原因となりやすいと考 えられる. Neuralでは, 完全障害でない場合 sensoryと 同じく，病的発火の原因となりやすく，注意が必要であ る. Neuralレベルの部分破壊では，もちろん，自発発火 は消失し，組織学的分類のうち，後障害はもっとも大き
いが，効果は確実である。

3）内耳の部分破壤・部分保存の可能性について

内耳は，別名「迷路」ともいわれるように，固い骨の 中のトンネルは, 迷路のごとく，また，中にある膜迷路 は，瀻細そのもので，極めて溒れやすい

解剖学的にみて, また, 生理学的にみて, 内耳の部分 的破壊は, 方法論的にも, 問題が多々 膜迷路は, 一つ ながりの袋状の器官なので, 一部分の破壊は, 全体の破 壊につながりやすく，また，仮に保存されたとしても， 必ずしも健全な状態で保存されるかどうかは疑問であ り，検討を必要とする。

組織学的分類によってこの問題を考えてみると, presensory の部分破壊は, 残存せしめる部分について, よ り健康な状態での保存が可能である場合が多く， neural の部分破壊では, 完全な部分破壞と, 残存部については より健康な保存が可能と考えられる. sensory の部分破 壊では，他の部分の保存について問題がもっとも大きい と考えられる。これについては，しかし，今日十分な結 論が得られていない. したがって, 臨床例にみる検討, 㐫るいは動物実験による機能的, および組織学的検討が 必要であると思われ，ヒトにもっとも近いサルについて の実験が目下進行中である。

これによると，1）三半規管の疎通性の遮断はもっと も安全な “presensory レベルの部分破壊”であった。 2）蝸牛部分を hook で切断し創口をシールすると, コ ルチ器の毛細胞が消失し, sensory deafness となるが, 
前庭・半規管は健康に保存された．3） 前庭神経上枝の 迷路骨包内での切断では, 卵形軎神経と前・外側半規管 神経は消失するが, 他の部分, とくに, 球形蝸牛 管, コルチ器などは, 全て健康に保存された（図 1).
以上，メニエール病を含む内耳病変に対する部分破填 術につき，とくに，迷路内手術侵變の可能性を理諭的， また，実験的検討を進めているので，その概要について 報告した。

\section{(発言)}

\section{一メ病手術の位置付けと shunt op. の問題点など—}

内藤售（阪大）

保存療法加ら手術まで非常に大きな幅を持つメ病の場 合，今日，世界各国で手術がどの上らに，どの位，行わ れつつあるか愲味深い点である。

われわれが昭和48年宿題報告の際行った外国へのアン ケート結果を見ると、メ病治療の方針は，返信のあった 174施設中，60\%保存療法，手術のどちらも，36\%は 保存療法のみ，4\%は手術のみを行っているという結果 であった．これは各施設のメ病治療に対する policy あ るいは philosophy を示しているものといえるが，この 中で特に興味梁く，かつ奇異にさえ感じられた点は，手 術のみを行っているといら施設のあったことで，日本で は一寸考えられないところである.

この点をも5少し分析して見ると，まず国民性の違、 というものがあげられると思う. 平たくいって欧米の方 が患者は医師のいらことをよくきき治潦に素直であるよ らな印象を受ける。これには医学あるいは医師に対する 信頼感 (この点われわれにも反省すべき点があるかもし れない）の問題も含まれるであろらし，また人生観とか 宗教心なども関係するであるらし，教養の高さ，社会文 化水準の違いとか，あるいは scientific に物事を考える 考え方の違いとか, Science そのものの人間社会におけ る位置すけけ違い，更にいらならば Science の生れた国 と輸入した国の違いとか，その他いろいろの要素が関保 すると思われる：また，手術すなわち身体を切るという ことに対する考え方も欧米と日本ではいささか違うよう でわれわれはなるべく切らずに治せるものなら切らず にすませたいと患者も医師も思いがちであるが，欧米で はもら少し radical に物事をわり切るのかもしれない． ともに身体を大切にするにしても，その仕方が少し違う ようである。
次に考えられることは，メ病そのものの様相が日本と 欧米では必ずしも同じではなく，欧米では激烈なメ病が 日本上り多い様で，最初から手術という policy の存在 する理由の一つはこういう点にむあるのかもしれない，

更にまた，社会事情の違い，すなわち高度文明社会の 一つの姿として，長期治療が日本上り困㐨で, 一日も早 く社会復帚をして仕事につかなければならないといら㖁 しさが日本より大きいとも考えられ，time is money 的 思想が日本より痛切なのであ万ら，医療費自体が日本よ り高くつくこともその理由の一つで長期沿療を避行，手 術へ直行することも考えられる。

また不測の医療事故に対する保倹システムが日本より 完備しているため，医師の方としても，上り安心して手 術にふみ切れるといらこともあるであろう。

さて, 次に, 只今司会の渡辺教授加ら日本と北米のメ 病手術の内容が示されたがここれと，われわれの行った 昭和48年のヨーロッパを含む欧米の統計とを比較して見 ると次のよらな面白い点にきずく。

すなわち, shunt op. に対しては渡辺教授の示された， 日本 $25 \%$, 北米 $26 \%$ に対し，われわれの欧米全体の統計 も24\%とほとんど同じで，このことは， shunt op.の evaluation, need, performance が世界的にほぼ同じレ゙ ルであることを示していると思われ，この手術が1926年 Portmann 以来今日まで立派な手術として認められてき た左証でむある。この手術が破壤的なものでなく，生理 的手術とさえいわれるところが最大の鬽力で，われわれ も愛用している所以である.

ところが，迷路破壊術となると，日本 $17.5 \%$ に対し北 米 $40.2 \%$, 欧米全体では $44 \% て ゙$, 日本と欧米との差が明 確になってくる，その理由は前述したとおりであると思 